\title{
A Comparative Study on the Breakdown Characteristics of SF6 and 20\% C3F7CN / $80 \%$ CO2 Gas Mixture in a Coaxial Configuration
}

DOI:

10.1109/CEIDP47102.2019.9009877

\section{Document Version}

Accepted author manuscript

Link to publication record in Manchester Research Explorer

Citation for published version (APA):

Loizou, L., Chen, T., \& Liu, Q. (2020). A Comparative Study on the Breakdown Characteristics of SF6 and 20\% C3F7CN / 80\% CO2 Gas Mixture in a Coaxial Configuration. In IEEE Conference on Electrical Insulation and Dielectric Phenomena https://doi.org/10.1109/CEIDP47102.2019.9009877

\section{Published in:}

IEEE Conference on Electrical Insulation and Dielectric Phenomena

\section{Citing this paper}

Please note that where the full-text provided on Manchester Research Explorer is the Author Accepted Manuscript or Proof version this may differ from the final Published version. If citing, it is advised that you check and use the publisher's definitive version.

\section{General rights}

Copyright and moral rights for the publications made accessible in the Research Explorer are retained by the authors and/or other copyright owners and it is a condition of accessing publications that users recognise and abide by the legal requirements associated with these rights.

\section{Takedown policy}

If you believe that this document breaches copyright please refer to the University of Manchester's Takedown Procedures [http://man.ac.uk/04Y6Bo] or contact uml.scholarlycommunications@manchester.ac.uk providing relevant details, so we can investigate your claim.

\section{OPEN ACCESS}




\title{
A Comparative Study on the Breakdown Characteristics of $\mathrm{SF}_{6}$ and $20 \% \mathrm{C}_{3} \mathrm{~F}_{7} \mathrm{CN} / 80 \% \mathrm{CO}_{2}$ Gas Mixture in a Coaxial Configuration
}

\author{
L. Loizou, L. Chen* and Q. Liu \\ Department of Electrical and Electronic Engineering \\ The University of Manchester \\ Manchester M13 9PL, UK \\ *lujia.chen@manchester.ac.uk
}

\begin{abstract}
Gas Insulated Lines (GIL) are considered an attractive alternative technology to overhead lines for transmission of high power over long distances. However, a key drawback is the use of sulphur hexafluoride $\left(\mathrm{SF}_{6}\right)$ as the main dielectric medium. $\mathrm{SF}_{6}$ is listed as a greenhouse gas with a Global Warming Potential (GWP) of 23,500 times higher than $\mathrm{CO}_{2}$. As $\mathrm{SF}_{6}$ is widely used in the power industry, there are increasing research activities to find a cost-effective and technically viable alternative candidate with significantly lower environmental impact. This paper investigates the feasibility of replacing $\mathrm{SF}_{6}$ in high voltage equipment with a more environmentally friendly gas named $\mathrm{C}_{3} \mathrm{~F}_{7} \mathrm{CN}$. A reduced-scale coaxial prototype was developed which replicates the quasi-uniform electric fields as found in a full-scale GIL. The test samples were subjected to standard lightning impulse $(1.2 / 50 \mu \mathrm{s})$ of both polarities. The results have shown that the mixture of $20 \% \mathrm{C}_{3} \mathrm{~F}_{7} \mathrm{CN} / 80 \% \mathrm{CO}_{2}$ can reach a dielectric strength equivalent to $100 \% \mathrm{SF}_{6}$ gas. In coaxial configurations, the positive lightning impulse breakdown voltage is in general higher than the negative polarity, especially at higher pressures. In conclusion, $\mathrm{C}_{3} \mathrm{~F}_{7} \mathrm{CN}$ mixtures can be a potential candidate of replacing $\mathrm{SF}_{6}$ for insulation applications such as gas insulated lines and busbars which is an encouraging step towards a more environmentally friendly future transmission network.
\end{abstract}

\section{INTRODUCTION}

Sulphur hexafluoride $\left(\mathrm{SF}_{6}\right)$ is widely used in gas insulated switchgear (GIS), lines (GIL) and busbars (GIB). Although $\mathrm{SF}_{6}$ is an ideal gas for insulation and arc-quenching purposes, its high environmental impact is a huge concern when it leaks into the atmosphere. The urgency in finding a suitable replacement is reflected by the recent EU F-gas regulation 2014 [1], since the use of $\mathrm{SF}_{6}$ has been restricted in some applications. However, $\mathrm{SF}_{6}$ is still widely used in the power industry as there is no readily available one-for-one replacement candidate. The initiative to replace $\mathrm{SF}_{6}$ in high voltage equipment applications within the power industry has been growing over the past few years and $\mathrm{C}_{3} \mathrm{~F}_{7} \mathrm{CN}$ gas is considered as one of the potential candidates.

$\mathrm{C}_{3} \mathrm{~F}_{7} \mathrm{CN}$, commercially known as Novec ${ }^{\mathrm{TM}} 4710$, is an odorless, colorless and non-flammable gas which belongs to the family of fluoronitrile gases [2]. It shares similar physical and chemical properties to $\mathrm{SF}_{6}$ such as being highly electronegative, chemically inert and non-ozone depleting. In its pure form, it has double the dielectric strength of $\mathrm{SF}_{6}$ with more desirable environmental properties [2]. In addition, the short atmospheric lifetime of $\mathrm{C}_{3} \mathrm{~F}_{7} \mathrm{CN}$ gas allows it to decompose within 30 years [3]. The main drawback of this gas is its high boiling point $\left(-4.7^{\circ} \mathrm{C}\right)$ which makes it necessary to mix it with a carrier gas such as $\mathrm{CO}_{2}$. Previous studies [3][4] have shown that a mixture of $\mathrm{CO}_{2}$ with $20 \% \mathrm{C}_{3} \mathrm{~F}_{7} \mathrm{CN}$ content has an equivalent dielectric strength to pure $\mathrm{SF}_{6}$ under disk and sphere-sphere electrode configurations. Therefore, this specific mixture was chosen to be investigated in this paper.

The research aim is to examine the differences in the breakdown characteristics of $100 \% \mathrm{SF}_{6}$ and the $20 \% \mathrm{C}_{3} \mathrm{~F}_{7} \mathrm{CN} /$ $80 \% \mathrm{CO}_{2}$ gas mixture using a coaxial test configuration. A reduced-scale coaxial prototype replicating the electric field distribution in gas insulated lines/busbars was developed to test both gases in quasi-uniform electric fields. Breakdown tests were conducted using the standard lightning impulse $(1.2 / 50 \mu \mathrm{s})$ of both polarities. The pressure and polarity effects on the breakdown voltage are compared between $\mathrm{SF}_{6}$ and the $20 \% \mathrm{C}_{3} \mathrm{~F}_{7} \mathrm{CN} / 80 \% \mathrm{CO}_{2}$ mixture.

\section{ENVIRONMENTAL IMPACT AND TOXICITY PROFILE}

$\mathrm{C}_{3} \mathrm{~F}_{7} \mathrm{CN}$ has a GWP of 2,100 [2] in its pure form but this reduces when the gas is used in low concentrations as part of a mixture. Fig. 1 shows the calculated GWP values based on the reduced density of the gas mixture. As anticipated, it shows that the GWP of a mixture decreases with lower $\mathrm{C}_{3} \mathrm{~F}_{7} \mathrm{CN}$ concentrations. The mixture investigated in this paper has a $20 \% \mathrm{C}_{3} \mathrm{~F}_{7} \mathrm{CN}$ content with a GWP of $\approx 1,100$, which represents a $95 \%$ reduction of $\mathrm{SF}_{6}$ [5].

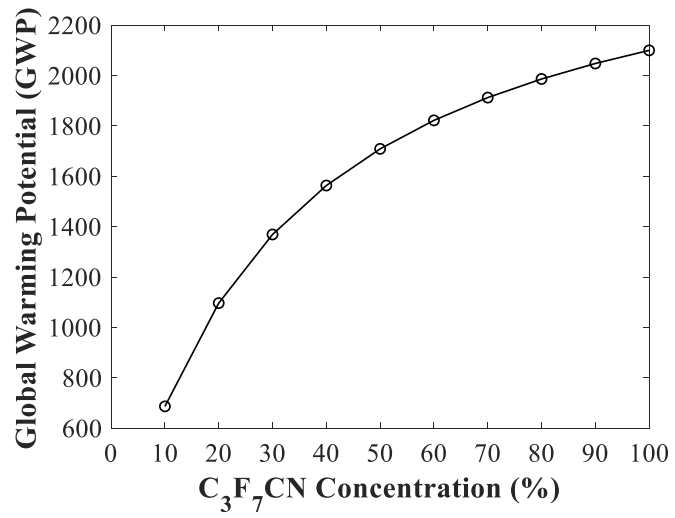

Fig. 1. Calculated GWP in relation to $\mathrm{C}_{3} \mathrm{~F}_{7} \mathrm{CN}$ concentration in a mixture. 
The toxicity profile of $\mathrm{C}_{3} \mathrm{~F}_{7} \mathrm{CN}$ has been addressed by previous studies where they report that its 4-hour $\mathrm{LC}_{50}$ (lethal concentration at $50 \%$ mortality) is between $10,000 \mathrm{ppmv}$ and 15,000 ppmv [3]. This value, just like the GWP, varies when using $\mathrm{C}_{3} \mathrm{~F}_{7} \mathrm{CN}$ as part of a mixture and according to CLP regulation 1272/2008 it is categorized as a practically nontoxic gas [6].

\section{EXPERIMENTAL SetUP AND PROCEDURE}

\section{A. Experimental Setup}

The experimental circuit diagram and setup are shown in Fig. 2 and 3(a) respectively. A stainless-steel pressure vessel that can go up to 10 bar (abs) was fabricated for the experimental investigation, as shown in Fig. 3(b). The pressure vessel has a $\mathrm{SF}_{6}$ bushing which can withstand $325 \mathrm{kV}$ $\mathrm{AC}$ and $750 \mathrm{kV}$ lightning impulse voltages. A 2 MV Haefely Marx impulse generator was used for generating the standard lightning impulse $(1.2 / 50 \mu \mathrm{s})$. Prior to any gas filling, the pressure vessel was filled with $\mathrm{CO}_{2}$ for an extended period to purge the impurity and absorb any residual moisture. The pressure chamber was then vacuumed down to 1 mbar and filled with the desired gas up to the chosen test pressure. For the $\mathrm{C}_{3} \mathrm{~F}_{7} \mathrm{CN} / \mathrm{CO}_{2}$ gas mixture, the gas was left in the pressure vessel for an extended period for the mixture to become homogeneous before any testing.

\section{B. Experimental Procedure}

The up-and-down procedure was used in accordance to BS EN 60060-1 [7] and the statistical analysis for determining the $50 \%$ breakdown voltage, $\mathrm{U}_{50}$, was carried out with the same

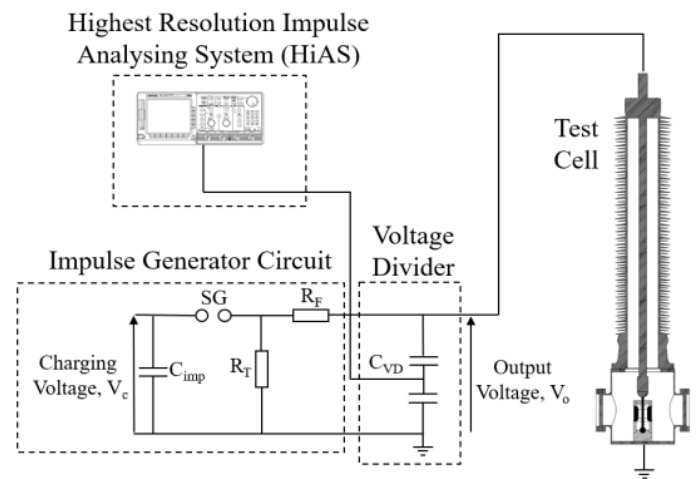

Fig. 2. Experimental test circuit.

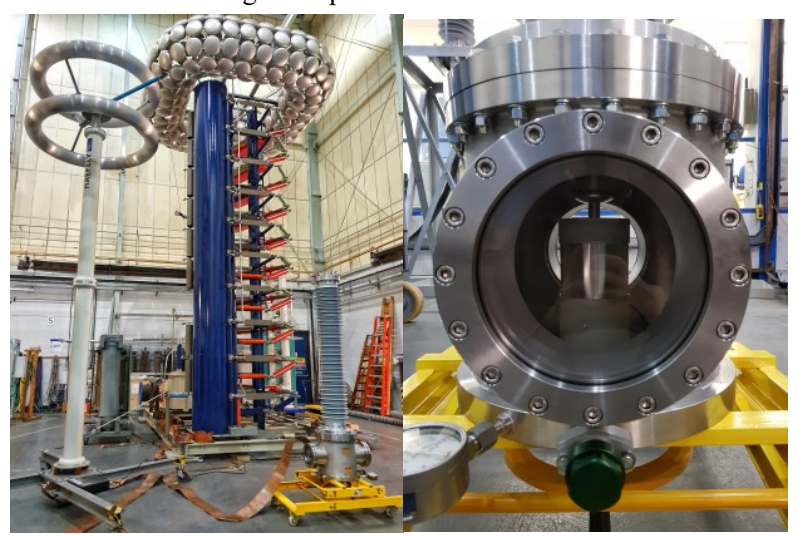

Fig. 3. (a) Experimental setup and (b) pressure vessel. method as described in [8]. A set of 30 impulses was used for the up-and-down procedure with a time interval of 2 minutes between each impulse.

\section{REDUCED-SCALE PROTOTYPE}

\section{A. Methodology and Simulation}

In coaxial configurations, there is a trade-off between the field uniformity and the gap spacing, ' $\mathrm{g}$ ', from the high voltage conductor to the grounded enclosure. It is well established that there is an optimal ratio between the design parameters shown in Fig. 4, which results in the lowest electric field intensity applied on the insulation [9]. The optimal ratio is $\mathrm{R}_{\mathrm{b}} / \mathrm{R}_{\mathrm{a}}=e$ or $\ln \left(\mathrm{R}_{\mathrm{b}} / \mathrm{R}_{\mathrm{a}}\right)=1$.

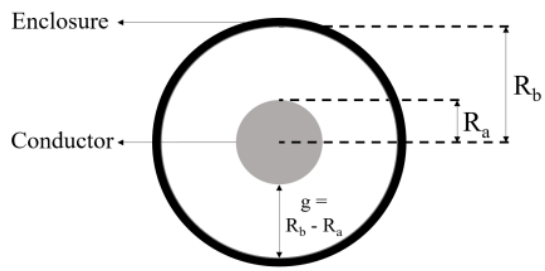

Fig. 4. Coaxial electrode design parameters.

Electric field computations were carried out using COMSOL 5.3 software to validate this theory and develop the optimized design for the coaxial electrode used in this paper. Fig. 5 shows how the conductor radius affects $E_{\max }$ and the field utilization factor of a coaxial arrangement with a $30 \mathrm{~mm}$ inner enclosure diameter. As shown in Fig. 5, using a conductor radius $\left(R_{a}\right)$ that exceeds the optimal ratio, the field becomes more uniform. However, as g becomes smaller the electric field intensity increases. Vice versa, with a conductor radius smaller than the optimal ratio, $g$ increases but the electric field becomes more divergent, which results in an increased electric field stress on the conductor surface. As anticipated from the theory [9], the coaxial design that has the lowest point on the $\mathrm{E}_{\max }$ curve shown in Fig. 5 and therefore most likely to have the maximum breakdown voltage is when the ratio of inner enclosure $\left(\mathrm{R}_{\mathrm{b}}\right)$ to outer conductor radius $\left(\mathrm{R}_{\mathrm{a}}\right)$ is almost equal to $\approx 3$.

\section{B. Geometric Dimensions of Coaxial Electrodes}

Fig. 6(a) shows the dimensions of the electrode fabricated for testing with a ratio of 3 for the inner enclosure to the outer

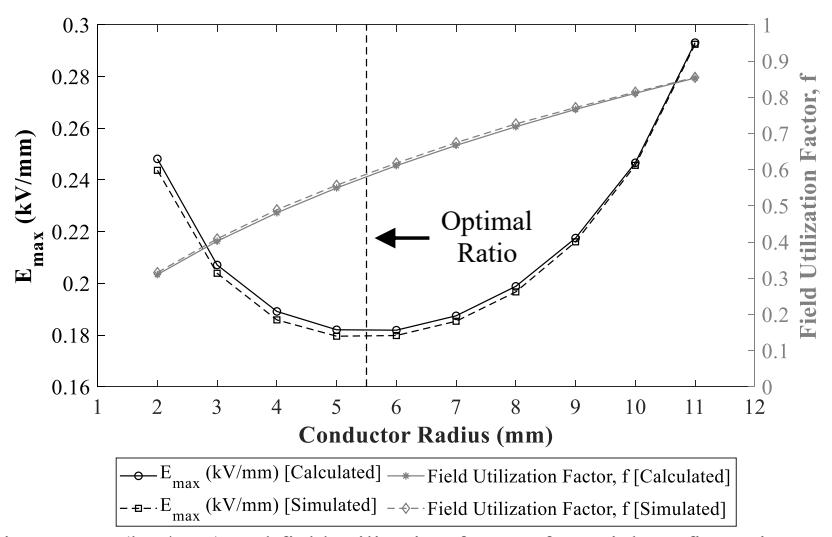

Fig. 5. $\mathrm{E}_{\max }(\mathrm{kV} / \mathrm{mm})$ and field utilization factor of coaxial configuration against conductor radius $(\mathrm{mm})$. 


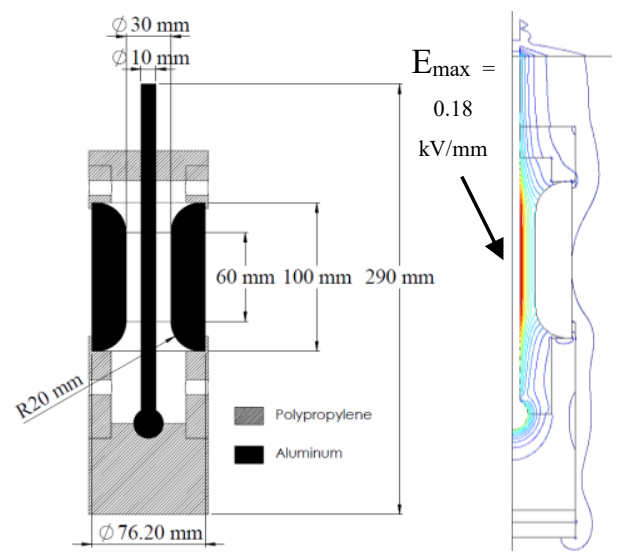

Fig. 6. (a) Reduced-scale prototype dimensions (b) $E_{\max }(\mathrm{kV} / \mathrm{mm})$ location.

conductor. The conductor and enclosure are both made of aluminum with a mirror-finish and an average surface roughness of $0.2 \mu \mathrm{m}$. Polypropylene insulators are used to center the conductor and provide sufficient clearance from the ground. Simulation was performed to ensure all the clearances are sufficient and the maximum electric field location is around the central region of the conductor, as illustrated in Fig. 6(b). This was achieved by keeping a safe distance from the bottom of the pressure vessel, terminating the conductor with a sphere and rounding the edges of the enclosure. These precautions maximize the likelihood of having breakdowns in the central region which is the area of interest for small-scale coaxial electrodes.

\section{EXPERIMENTAL RESULTS AND DISCUSSION}

\section{A. Breakdown Characteristics}

Fig. 7 shows that the breakdown trends of $\mathrm{SF}_{6}$ and $20 \%$ $\mathrm{C}_{3} \mathrm{~F}_{7} \mathrm{CN} / 80 \% \mathrm{CO}_{2}$ gas mixture behave in a similar way under positive lightning impulse, i.e. breakdown voltage increases linearly with pressure. As shown in Fig. 7, the $\mathrm{C}_{3} \mathrm{~F}_{7} \mathrm{CN} / \mathrm{CO}_{2}$ gas mixture has a breakdown voltage almost equivalent to $\mathrm{SF}_{6}$. The largest difference between the two gases is at 3 bar (abs) where $\mathrm{SF}_{6}$ is around $19 \mathrm{kV}(11 \%)$ higher than the $\mathrm{C}_{3} \mathrm{~F}_{7} \mathrm{CN} / \mathrm{CO}_{2}$ gas mixture.

Fig. 8 compares the breakdown voltage of the two gases under negative lightning impulse. Again, breakdown voltage

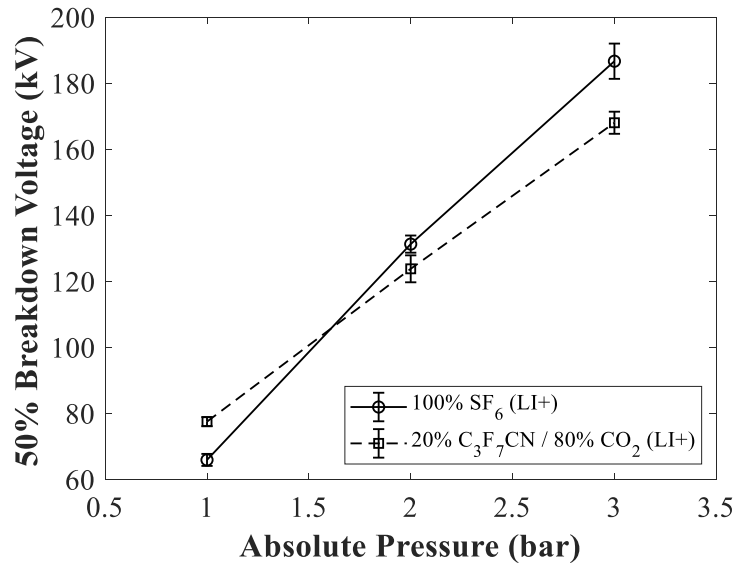

Fig. 7. $\mathrm{U}_{50}$ as a function of absolute pressure in coaxial electrode configuration for $\mathrm{SF}_{6}$ and $20 \% \mathrm{C}_{3} \mathrm{~F}_{7} \mathrm{CN} / 80 \% \mathrm{CO}_{2}$ under positive lightning impulse (LI+).

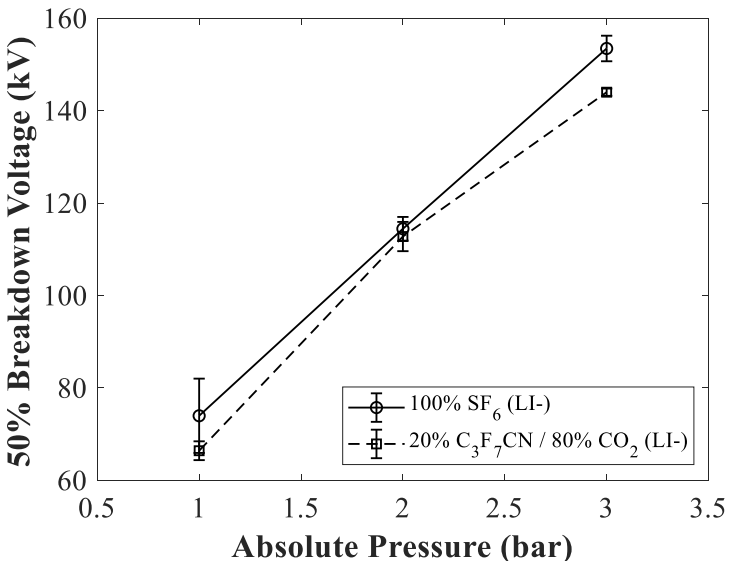

Fig. 8. $\mathrm{U}_{50}$ as a function of absolute pressure in coaxial electrode configuration for $\mathrm{SF}_{6}$ and $20 \% \mathrm{C}_{3} \mathrm{~F}_{7} \mathrm{CN} / 80 \% \mathrm{CO}_{2}$ under negative lightning impulse (LI-).

increases linearly with pressure. It shows that under negative lightning impulse the difference between $\mathrm{SF}_{6}$ and the $\mathrm{C}_{3} \mathrm{~F}_{7} \mathrm{CN} / \mathrm{CO}_{2}$ gas mixture is less than it is under the positive polarity. The lowest difference between the two values is at 2 bar (abs) where $\mathrm{SF}_{6}$ is just $2 \mathrm{kV}(1.5 \%)$ higher than $\mathrm{C}_{3} \mathrm{~F}_{7} \mathrm{CN} / \mathrm{CO}_{2}$.

As shown in Fig. 7 and 8, the results of this paper come into good agreement with previous investigations [3][4] where they tested the breakdown characteristics of similar gas mixtures using disk and sphere-sphere electrode geometries.

B. Pressure Reduced Breakdown Field Strength $\left(E_{b} / p\right)_{\max }$

The pressure reduced breakdown field strength $\left(\mathrm{E}_{\mathrm{b}} / \mathrm{p}\right)_{\max }$ is calculated using (1) by assuming that the breakdown field strength of the coaxial electrode is given with the breakdown voltage value $\left(\mathrm{U}_{\mathrm{b}}\right)$ where $\mathrm{U}_{\mathrm{b}}=\mathrm{U}_{50}$. Fig. 9 shows that $\left(\mathrm{E}_{\mathrm{b}} / \mathrm{p}\right)_{\max }$ reduces as pressure increases and only the 3 bar, negative polarity value of the $\mathrm{C}_{3} \mathrm{~F}_{7} \mathrm{CN} / \mathrm{CO}_{2}$ mixture falls slightly below the $(\mathrm{E} / \mathrm{p})_{\text {crit }}$ value of $\mathrm{SF}_{6}$ gas. The $(\mathrm{E} / \mathrm{p})_{\text {crit }}$ value is where the attachment coefficient $(\eta)$ of an electronegative gas is equal to

$$
\left(E_{b} / p\right)_{\text {max }}=\frac{U_{50}}{R_{a} \cdot \ln \left(\frac{R_{b}}{R_{a}}\right) \cdot p}(\mathrm{kV} / \mathrm{mm} \cdot \mathrm{bar})
$$

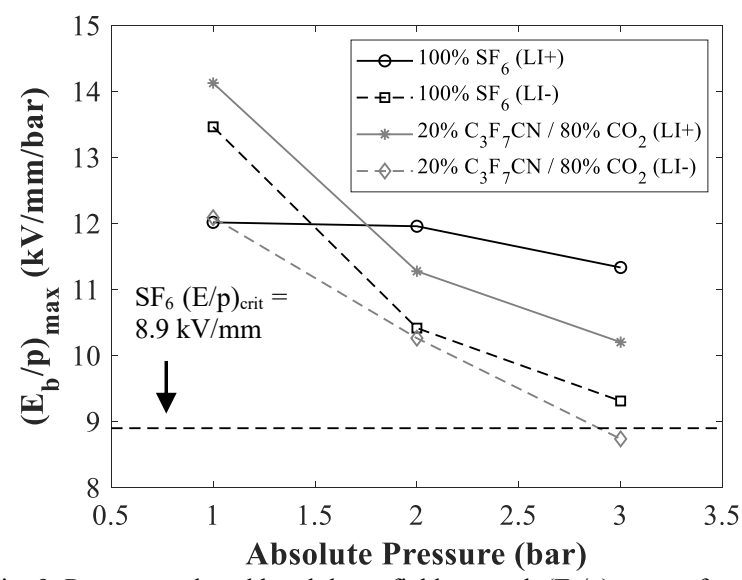

Fig. 9. Pressure reduced breakdown field strength $\left(\mathrm{E}_{\mathrm{b}} / \mathrm{p}\right)_{\max }$ as a function of pressure for $\mathrm{SF}_{6}$ and $20 \% \mathrm{C}_{3} \mathrm{~F}_{7} \mathrm{CN} / 80 \% \mathrm{CO}_{2}$ in coaxial electrode configuration under lightning impulse waveform (LI). 
the ionization coefficient $(\alpha)[\alpha=\eta]$ and discharge growth is not likely to occur at this value. An electric field higher than this critical point $\left[\mathrm{E} / \mathrm{p}>(\mathrm{E} / \mathrm{p})_{\text {crit }}\right]$ brings an inbalance between $\alpha$ and $\eta(\alpha>\eta)$ which leads to cumulative ionisation and most likely a breakdown. In contrast, electric fields lower than this value $\left[\mathrm{E} / \mathrm{p}<(\mathrm{E} / \mathrm{p})_{\text {crit }}\right]$ are not likely to lead to a breakdown. Fig. 9 shows that $(\mathrm{E} / \mathrm{p})_{\text {crit }}$ of $20 \% \mathrm{C}_{3} \mathrm{~F}_{7} \mathrm{CN} / 80 \% \mathrm{CO}_{2}$ might be slightly lower, small difference, than pure $\mathrm{SF}_{6}$ which has to be accounted when designing GIL/GIB for a new gas candidate.

\section{Polarity Effect under Lightning Impulse}

Fig. 10 compares $\mathrm{SF}_{6}$ and $20 \% \mathrm{C}_{3} \mathrm{~F}_{7} \mathrm{CN} / 80 \% \mathrm{CO}_{2}$ gas mixture under lightning impulse of both polarities. As seen from Fig. 10, negative polarity tends to have a lower breakdown voltage than the positive. The distinction in breakdown voltage due to polarity becomes larger as the pressure increases. This is shown in Fig. 10 where the difference between positive and negative breakdown voltages for $\mathrm{SF}_{6}$ increases from $17 \mathrm{kV}$ to $33 \mathrm{kV}$ from 2 bar to $3 \mathrm{bar}$, respectively. The same behaviour is noticed for $\mathrm{C}_{3} \mathrm{~F}_{7} \mathrm{CN} / \mathrm{CO}_{2}$ mixture where the difference between positive and negative polarities grows from $11 \mathrm{kV}$ at 2 bar to around $24 \mathrm{kV}$ at 3 bar.

Fig. 11 compares $20 \% \mathrm{C}_{3} \mathrm{~F}_{7} \mathrm{CN} / 80 \% \mathrm{CO}_{2}$ to $30 \% \mathrm{CF}_{3} \mathrm{I} /$ $70 \% \mathrm{CO}_{2}$ gas mixture which was investigated in [10] using a similar dimensioned coaxial model. The same difference in the

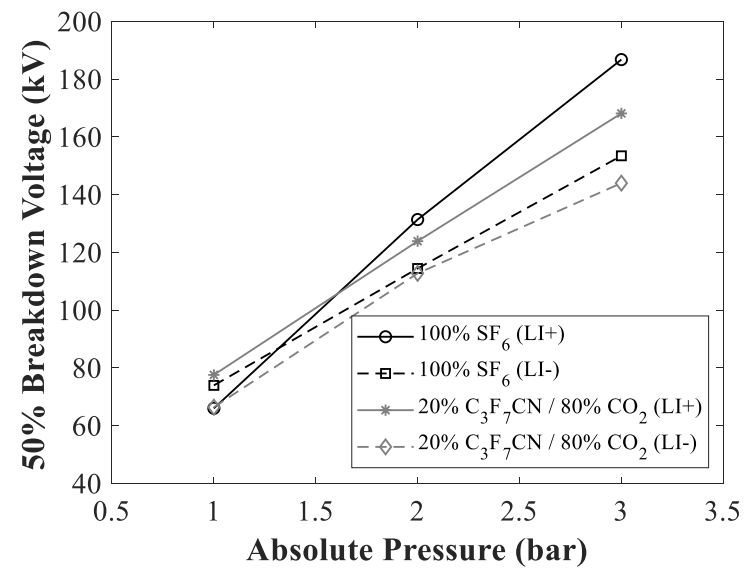

Fig. 10. $\mathrm{U}_{50}$ as a function of absolute pressure in coaxial electrodes for $\mathrm{SF}_{6}$ and $20 \% \mathrm{C}_{3} \mathrm{~F}_{7} \mathrm{CN} / 80 \% \mathrm{CO}_{2}$ under lightning impulse.

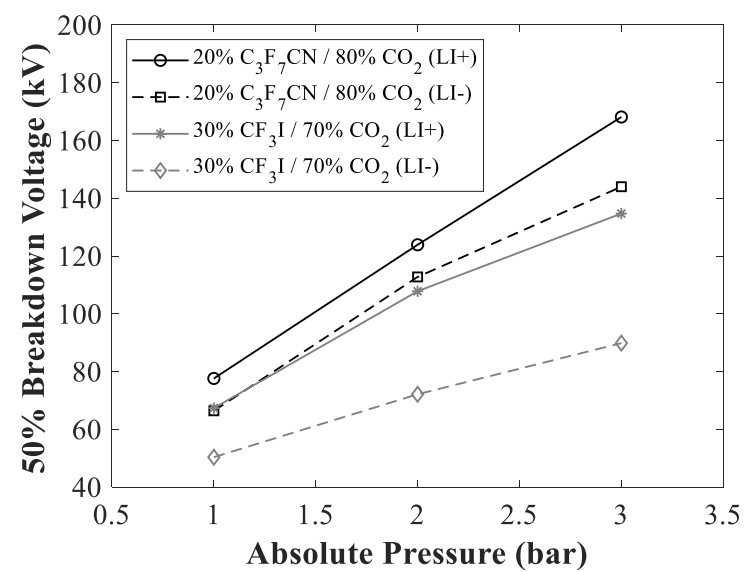

Fig. 11. $\mathrm{U}_{50}$ as a function of absolute pressure in coaxial electrodes for $20 \%$ $\mathrm{C}_{3} \mathrm{~F}_{7} \mathrm{CN} / 80 \% \mathrm{CO}_{2}$ and $30 \% \mathrm{CF}_{3} \mathrm{I} / 70 \% \mathrm{CO}_{2}[10]$ under lightning impulse. breakdown voltage due to lightning impulse polarity was found in [10]. This suggests that the polarity effect is not occurring because of different gases but because of the specific electric field type tested. The different gas, however, does look to change the magnitude of the difference as it can be seen from Fig. 11 that the distinction between positive and negative polarities for $\mathrm{CF}_{3} \mathrm{I} / \mathrm{CO}_{2}$ is much more evident than the $\mathrm{C}_{3} \mathrm{~F}_{7} \mathrm{CN} / \mathrm{CO}_{2}$ gas mixture.

\section{CONCLUSION}

The results of this paper show that a mixture of buffer gas with $20 \% \mathrm{C}_{3} \mathrm{~F}_{7} \mathrm{CN}$ content can be a promising candidate to replace $\mathrm{SF}_{6}$ in high voltage applications. Using a quasiuniform coaxial electrode configuration, the $20 \% \mathrm{C}_{3} \mathrm{~F}_{7} \mathrm{CN} /$ $80 \% \mathrm{CO}_{2}$ mixture has demonstrated to have a breakdown voltage comparable to pure $\mathrm{SF}_{6}$, especially under negative lightning impulse polarity. Additionally, the breakdown voltage of both gases rises with increasing pressure with a similar rate of change.

This paper has also shown that negative polarity breakdown voltage tends to be lower than positive using this electrode configuration. This indicates that for gas insulated equipment with a coaxial geometry, the negative polarity is more critical in the design consideration.

\section{ACKNOWLEDGMENT}

This work was supported in part by a Ph.D. studentship from the Engineering and Physical Sciences Research Council (EPSRC), Industrial Cooperative Awards in Science \& Technology, and in part by National Grid, UK.

\section{REFERENCES}

[1] The European Parliament and the Council of the European Union, "Regulation (EU) No 517/2014 of the European Parliament and of the Council of 16 April 2014 on fluorinated greenhouse gases and repealing Regulation (EC) No 842/2006," Off. J. Eur. Union, vol. 2014, no. 517, p. L150/195-230, 2014.

[2] $3 \mathrm{M}$ Electronics Materials Solutions Division, " $3 \mathrm{M}^{\mathrm{TM}} \mathrm{Novec}^{\mathrm{TM}} 4710$ Insulating Gas." 2017.

[3] J. G. Owens, "Greenhouse Gas Emission Reductions through use of a Sustainable Alternative to $\mathrm{SF}_{6}$," in IEEE Electrical Insulation Conference (EIC), 2016, pp. 535-538.

[4] A. Hopf, J. A. Britton, M. Rossner, and F. Berger, "Dielectric Strength of $\mathrm{SF}_{6}$ Substitutes, Alternative Insulation Gases and PFCGas-Mixtures," in IEEE Electrical Insulation Conference (EIC), 2017, no. June, pp. 209-212.

[5] IPCC, "Climate Change 2013: The Physical Science Basis. Working Group I Contribution to the Fifth Assessment Report on Interngovernmental Panel on Climate Change," 2013.

[6] Y. Kieffel, "Characteristics of $\mathrm{g} 3$ - An alternative to $\mathrm{SF}_{6}$," in IEEE International Conference on Dielectrics (ICD), 2016, pp. 880-884.

[7] "BS EN 60060-1:2010: High-Voltage test techniques, Part 1: General Definitions and test requirements," Br. Stand. Institutions.

[8] L. Loizou, L. Chen, and Q. Liu, "Breakdown Characteristics of $\mathrm{C} 3 \mathrm{~F} 7 \mathrm{CN} / \mathrm{CO} 2$ Gas Mixtures in Rod-Plane Gaps," in IEEE International Conference on High Voltage Engineering and Application (ICHVE), 2018.

[9] E. Kuffel, W. S. Zaengl, and J. Kuffel, High Voltage Engineering Fundamentals, vol. 2. Pergamon Press, 2001.

[10] L. Chen, H. Griffiths, A. Haddad, and M. S. Kamarudin, "Breakdown of $\mathrm{CF}_{3} \mathrm{I}$ Gas and its Mixtures under Lightning Impulse in Coaxial-GIL Geometry," IEEE Trans. Dielectr. Electr. Insul., vol. 23, no. 4, pp. 1959-1967, 2016. 